\title{
Rosin maleic anhydride adduct antibacterial activity against methicillin-resistant Staphylococcus aureus
}

\author{
Zahid Majeed ${ }^{1 * \#}$ (D), Muhammad Mushtaq ${ }^{1 *}$ (D), Zainab Ajab² (D), Qingjie Guan² (D), \\ Mater Hussen Mahnashi ${ }^{3}$ (D), Yahya Saeed Alqahtani ${ }^{3}$ (D) and Basharat Ahmad ${ }^{4}$ (D)
}

\author{
${ }^{1}$ Environmental Biotechnology Laboratory, Department of Biotechnology, University of Azad Jammu and \\ Kashmir, Chehla Campus, Muzaffarabad, Azad Kashmir, Pakistan \\ ${ }^{2}$ Key Laboratory of Saline-alkali Vegetation Ecology Restoration, Ministry of Education, \\ College of Life Sciences, Northeast Forestry University, Harbin, Heilongjiang, China \\ ${ }^{3}$ Department of Pharmaceutical Chemistry, College of Pharmacy, Najran University, \\ Najran, Kingdom of Saudi Arabia \\ ${ }^{4}$ Department of Zoology, University of Azad Jammu and Kashmir, Chehla Campus, Muzaffarabad, \\ Azad Kashmir, Pakistan \\ *zahidfdb@gmail.com; zahid.majeed@ajku.edu.pk \\ \#Zahid Majeed and Muhammad Mushtaq contributed equally as first author.
}

\begin{abstract}
The emergence of antibiotic resistance in microorganisms is a serious challenge globally. Natural hydrophobic diterpene carboxylic acids present in rosin have unsatisfactory inhibitory properties against pathogens due to their poor water solubility. Therefore, the objective of research work was to modify the natural rosin into rosin maleic anhydride adduct with improved bioinhibitory properties for methicillin-resistant Staphylococcus aureus (MRSA). Prescreened MRSA isolates were found $78.05 \%$ and $29.27 \%$ resistant to oxacillin and vancomycin antibiotics respectively. The dosage effect of $0,25,50$, and $100 \mathrm{mg} \mathrm{L}^{-1}$ rosin maleic anhydride adduct revealed the best inhibition response at $25 \mathrm{mg} \mathrm{L}^{-1}$. Moreover, bacteriostatic as well as the inhibitory effect of rosin maleic anhydride adduct was noticed against MRSA isolates. Gompertz model predicted better uptake of maleic anhydride adduct as compared to rosin. The higher specific growth rate of MRSA at reduced lag time correlated with increased toxicity of maleic anhydride adduct. This research concludes rosin maleic anhydride adduct has superior inhibitory properties against MRSA strains.
\end{abstract}

Keywords: drug resistance, growth kinetics, growth inhibition, MRSA, rosin maleic anhydride adduct.

How to cite: Majeed, Z., Mushtaq, M., Ajab, Z., Guan, Q., Mahnashi, M. H., Alqahtani, Y. S., \& Ahmad, B. (2020). Rosin maleic anhydride adduct antibacterial activity against methicillin-resistant Staphylococcus aureus. Polimeros: Ciência e Tecnologia, 30(2), e2020022. https://doi.org/10.1590/0104-1428.03820

\section{Introduction}

MRSA is a multidrug-resistant gram-positive resistant bacterium and it is a worldwide challenge for all clinicians to treat this Methicillin Resistant $S$. aureus (MRSA) infection. The resistant strain of MRSA, which acquired resistance against oxacillin/methicillin and other antibiotics that contain $\beta$-lactam rings in their structure. Currently, vancomycin inhibits MRSA strains in the range of 1.0-2.0 $\mu \mathrm{g} \mathrm{mL}^{-1}$. Until today, vancomycin has shown excellent activity against clinical isolates of MRSA ${ }^{[1]}$. However, vancomycin resistance is relatively a new pattern in emerging MRSA strains. MRSA causes intractable human infections ${ }^{[2]} \cdot \beta$-lactamase mediated resistance in $S$. aureus has been developed within the last decade due to the overuse of penicillin ${ }^{[3,4]}$. Besides, the production of Penicillin-binding proteins $2 \mathrm{a}$ (PBP2a) in MRSA is responsible for the development of $S$. aureus resistance to methicillin antibiotics. This protein was encoded by the mecA, a gene that is placed on chromosome mec cassette - a mobile genetic element (MGE) of $S$. aureus.

It shows a very low affinity against antibiotics that contain $\beta$-lactam ring ${ }^{[5,6]}$. Due to this fact, the resistance of $S$. aureus against antibiotics of many classes is a current challenge for all physicians that work in a hospital environment to cure infections caused by MRSA ${ }^{[7]}$.

Rosin consists of abietic acid, pimaric acid, and labdane acids. Abietic acid and dehydroabietic acid are potent compounds against bacteria ${ }^{[8]}$. Augmenting the rosin concentration is known for an increase in the microbicidal effect of the rosin against $S$. aureus, MRSA, Escherichia coli (E. coli), Pseudomonas aeruginosa, Bacillus subtilis, and Candida albicans. The minimum concentration of rosin $10 \%(\mathrm{w} / \mathrm{w})$ has prevented the growth of the microbes in the rosin-salve media ${ }^{[9]}$. Antibacterial activity of reduced gum rosin-acrylamide copolymer-based novel nanogel have shown 19.3-19.8 $\mathrm{mm}$ and 11.2-12.5 $\mathrm{mm}$ of the zone of inhibition against $S$. aureus and $E$. coli respectively ${ }^{[10]}$. Rosin acids-loaded polyethylene glycol-poly(lactic-co-glycolic acid) 
nanoparticles are known with enhanced antimicrobial properties against foodborne bacterial pathogens ${ }^{[1]}$. Rosin acid and their derived nanoparticles were strongly active against antibiotic-resistant $S$. aureus.

Earlier mechanisms of rosin activity revealed that the coniferous rosin destroys the bacterial cell wall and cell membrane. In electrophysiologic experiments, the rosin exposure decreased the cell membrane proton gradient in bacterial cells. This phenomenon is associated with the disruption of proton transport in the membrane-bound ATPase, and resulting in uncoupling of the oxidative phosphorylation. It results in cell metabolism would cease and the supply of energy is lost. By electron microscopy, an increase in the thickness of the cell wall promotes cell to cell aggregation which facilitated by rosin and lysis of bacterial cells finally occur. Based on literature studies, it is evident that rosin has poor antibacterial properties. The improvement of its inhibitory properties with maleic anhydride for its use as a drug against MRSA is not studied yet. To overcome MRSA drug resistance, this research proposed the use of rosin modified with maleic anhydride adduct ${ }^{[12]}$ as an antibacterial drug. There are limited studies that have used the rosin as an antimicrobial drug against MRSA ${ }^{[2]}$. Rosin's reaction with maleic anhydride has been reported for rosin maleic anhydride adduct. Maleic anhydride has increased the water solubility in water in a $\mathrm{pH}$-dependent manner ${ }^{[13]}$.

Pine trees are abundantly present in Azad Jammu and Kashmir, Pakistan which are biofactories for natural rosin which are composed of acids known for their promising antimicrobial activity. These acids are abietic acid, dehydroabietic acid, and the less stable acids of the abietadiene-type (levopimaric acid, palustric acid, and neoabietic acid ${ }^{[14]}$. Under this work, we prepared different concentrations of rosin maleic anhydride adduct with improved solubility than rosin and evaluated inhibitory properties against MRSA screened from different infected patients visited Combined Military Hospital Muzaffarabad, Azad Jammu, and Kashmir, Pakistan.

\section{Materials and Methods}

\subsection{Media and reagents}

Mannitol Salt Agar (99\%), Muller-Hunton Agar, Nutrient Broth were purchased from Sigma Aldrich (USA). Antibiotics (Oxacillin, Vancomycin, Cefoxitin, Piperacillin, Tazobactam, Fosfomycin, Cephradine, Amoxicillin) a product of Oxoid, (UK) were used. Rosin (Mw $303 \mathrm{~g} / \mathrm{mol})^{[15,16]}$ of P. roxburghii was provided by the Environmental Biotechnology Laboratory of the Department of Biotechnology, University of Azad Jammu and Kashmir, Muzaffarabad. Any plant residues present in rosin were removed manually, and purified it after passing melted rosin through $0.1 \mathrm{~mm}$ mesh strainer.

\subsection{MRSA screening}

\subsubsection{Infectious samples collection}

Total 60 clinical isolates were screened from different infectious samples of pus, urine, blood, ear swab, vaginal fluid submitted to Microbiology Laboratory of Combined
Military Hospital, Muzaffarabad, Azad Jammu and Kashmir during Year - 2019.

\subsubsection{Culturing, isolation, and identification of $S$. aureus}

The collected samples were enriched in nutrient broth and incubated for $24 \mathrm{~h}$ at $37^{\circ} \mathrm{C}$. After this, the broth was immediately streaked on Nutrient Agar plate under sterile conditions and incubated further at $37^{\circ} \mathrm{C}$ for $24 \mathrm{~h}$. Microbial colonies were further isolated for the identification of $S$. aureus. For $S$. aureus identification, isolates were cultured on Mannitol Salt Agar as a specific media for $S$. aureus at $37^{\circ} \mathrm{C}$ for $24 \mathrm{~h}$ for colony appearance and identification. S. aureus was identified by observing a yellow colony and yellowish background on Mannitol Salt Agar ${ }^{[17]}$. Catalase and coagulase tests ${ }^{[18]}$ tests were conducted for confirmation of S. aureus. In a catalase-positive test, bacterial colonies produced bubbles after adding and homogenizing with 1-2 drops of $3 \% \mathrm{H}_{2} \mathrm{O}_{2}$. For a positive coagulase test, one drop of plasma citrate added to 1-2 bacterial colonies which developed plasma flocculation. Out of non-duplicate 60 samples, 41 (68.3\%) samples were detected positive for $S$. aureus. Isolates of $S$. aureus $(\mathrm{N}=41)$ recovered was as follows; $17(41.46 \%)$ from pus, urine $10(24.39 \%)$, vaginal fluid $6(14.63 \%)$, blood $3(7.32 \%)$, ear swab $3(7.32 \%)$, and other body fluid $2(4.88 \%)$. Maximum number/percentage of $S$. aureus in pus followed by urine. The lowest number or percentage of $S$. aureus recovered in other body fluids.

\subsubsection{Antibiotics sensitivity screening of $S$. aureus and detection of MRSA}

Antibiotics susceptibility testing was performed using the disc diffusion method as per the criteria are given by the British Society for Antimicrobial Chemotherapy ${ }^{[19]}$. Antimicrobial drug susceptibility testing was performed against all isolates of $S$. aureus by using a modified disk diffusion method. About 3-5 selected colonies of bacteria were taken from the pure culture and transferred to a tube containing $5 \mathrm{~mL}$ of distilled water and mixed gently until a homogenous suspension was formed. The suspension mixture distributed the bacteria over the entire surface of Mueller-Hinton agar. The following concentrations of antibiotics were tested against $S$. aureus: oxacillin, $1 \mu \mathrm{g}$; amoxicillin, $25 \mu \mathrm{g}$; cefoxitin, $30 \mu \mathrm{g}$; vancomycin, $30 \mu \mathrm{g}$, piperacillin/tazobactam, $110 \mu \mathrm{g}$; fosfomycin, $50 \mu \mathrm{g}$.

All the $S$. aureus strains were tested against oxacillin disk by using the disk diffusion method which is a benchmark for MRSA. The oxacillin disk was applied on the Mueller-Hinton agar plate against $S$. aureus and incubated at $37^{\circ} \mathrm{C}$ for $24 \mathrm{~h}$. After this incubation period, oxacillin resistant strains were confirmed for MRSA according to the zone of inhibition (ZOI) measured against $S$. aureus.

\section{Oxacillin}

$\mathrm{ZOI} \leq 10 \mathrm{~mm}$ - MRSA

ZOI 11-12 mm - intermediate sensitivity

ZOI was $\geq 13 \mathrm{~mm}$ then it is methicillin-sensitive S. aureus (MSSA)

All these resistant strains were further re-confirmed by testing against cefoxitin disk and incubated at $37{ }^{\circ} \mathrm{C}$ for $24 \mathrm{~h}$. After this incubation the ZOI was measured by using the following scale 


\section{Cefoxitin}

$$
\mathrm{ZOI} \leq 21 \mathrm{~mm}-\mathrm{MRSA}
$$$$
\mathrm{ZOI} \geq 22 \mathrm{~mm}-\mathrm{MSSA}
$$

This technique was adopted as an agreement standard by the Clinical and Laboratory Standards Institute (CLSI) ${ }^{[20,21]}$.

The distribution of $S$. aureus in different clinical samples was determined. Table 1 details the antibiotics sensitivity and resistivity trends found in $S$. aureus. Antibiotic susceptibility test was performed against $(\mathrm{N}=41) S$. aureus through the disk diffusion method. The $S$. aureus confirmed isolates were $32(78.05 \%)$ resistant, $9(21.95 \%)$ sensitive to oxacillin (Table 1). The antibiotics piperacillin/tazobactam $(85.37 \%)$ and vancomycin $(70.73 \%)$ showed maximum sensitivity against $S$. aureus and higher resistance to amoxicillin, $(82.93 \%)$ fosfomycin, $(80.49 \%)$ and oxacillin $(78.05 \%)$. These isolates show maximum sensitivity for piperacillin/ tazobactam and higher resistance against amoxicillin.

\subsection{Rosin maleic anhydride adduct antimicrobial sensitivity}

\subsubsection{Synthesis of Rosin maleic anhydride}

For conversion of rosin into rosin maleic anhydride adduct, conditions for synthesis, a scheme for chemical reactions, confirmation of chemical structure by infrared spectroscopy are reported in detail in our previous published research work ${ }^{[15]}$.

\subsubsection{Antimicrobial sensitivity}

\subsubsection{Disk diffusion assay}

To estimate the antibacterial effects of rosin and rosin maleic anhydride, the well diffusion method was used. During this method, the rosin and rosin maleic anhydride adduct were melted separately and placed thereafter on an aluminum file until they solidify. After that it was ground into smaller pieces, added acetone for dissolution and after that 10 times diluted with distal water to obtain concentration 25, 50, 100, and $150 \mathrm{mg} \mathrm{L}^{-1[12]}$. The Muller Hinton Agar was prepared by using distal water and autoclave at $121^{\circ} \mathrm{C}$ for $1 \mathrm{~h}$. After this, $1 \mathrm{~mL}$ of bacterial broth mixed with $20 \mathrm{~mL}$ of Muller-Hinton Agar and poured into Petri plates and left for solidification. Wells were formed by using the yellow tip and pouring rosin suspension into the well in different concentrations after that plate was incubated at $37^{\circ} \mathrm{C}$ for $24 \mathrm{~h}$. The zone of inhibition was measured by using Vernier caliper (Mitutoyo, Japan).

Table 1. Sensitivity and resistivity pattern of $S$. aureus against antibiotics.

\begin{tabular}{lcc}
\hline \multirow{2}{*}{ Antibiotic } & \multicolumn{2}{c}{ S. aureus $(\boldsymbol{N}=\mathbf{4 1})$} \\
\cline { 2 - 3 } & $\begin{array}{c}\text { Sensitive \% } \\
\text { (No. of isolates) }\end{array}$ & $\begin{array}{c}\text { Resistant \% } \\
\text { (No. of isolates) }\end{array}$ \\
\hline Oxacillin & $21.95(9)$ & $78.05(32)$ \\
Vancomycin & $70.73(29)$ & $29.27(12)$ \\
Cefoxitin & $26.83(11)$ & $73.17(30)$ \\
Piperacillin/Tazobactum & $85.37(35)$ & $14.63(6)$ \\
Fosfomycin & $19.51(8)$ & $80.49(33)$ \\
Cephradine & $41.46(17)$ & $58.54(24)$ \\
Amoxicillin & $17.07(7)$ & $82.93(34)$ \\
\hline
\end{tabular}

The shake tube method was used to quantitatively evaluate the antibacterial activity ${ }^{[22]}$. The ultraviolet light under laminar flow was used for the sterilization of rosin and rosin maleic anhydride adduct before use. The $S$. aureus culture of $10 \mathrm{~mL}$ (diluted to $10^{3}$ fold of the original level) added separately with $0.1 \mathrm{~mL}$ of rosin and rosin maleic anhydride adduct. Then, the two test tubes were shaken in the shaking incubator (IRMECO, GmbH Germany) with $120 \mathrm{rpm}$ for $24 \mathrm{~h}$ at $37^{\circ} \mathrm{C} .10 \mathrm{~mL}$ of the stimulated bacterial solution was diluted and spread on the agar plate, individually. The quality of bacterial colonies on the agar plate after incubating for $24 \mathrm{~h}$ at $37^{\circ} \mathrm{C}$ was counted on the colony counter (Galaxy 230 - Rocker Scientific Co., Ltd, Taiwan). Bacterial reduction percentage was calculated by the following Equation 1:

$$
\mathrm{R}=\left(\frac{\mathrm{B}-\mathrm{A}}{\mathrm{B}}\right) \times 100
$$

Where percentage bacterial reduction is represented by " $R$ ". The quality of live bacterial cells in the flask after shaking is represented by "B". The quality of live bacterial cells in the flask before shaking is represented by " $\mathrm{A}$ ".

\subsubsection{Growth kinetics}

The antimicrobial testing of $S$. aureus was performed qualitatively by using turbidity analysis on the spectrophotometer. The pure 3-5 selected colonies of $S$. aureus were cultured into the nutrient broth in $20 \mathrm{~mL}$ glass test tube and incubate at $37^{\circ} \mathrm{C}$ for $24 \mathrm{~h}$. After $24 \mathrm{~h}$ incubation, the fresh culture of these bacteria was re-cultured in nutrient broth 10:1 (10:1 mL bacterial culture) into three test tubes. The rosin and rosin maleic anhydride concentration 25,50 , and $100 \mathrm{mg} \mathrm{L}^{-1}$ were used for screening of inhibitory and bactericidal activity against MRSA. All tubes were incubated in a shaking incubator at $37^{\circ} \mathrm{C}$ for $24 \mathrm{~h}$. Colonies were counted on the colony counter prior to the start of the experiment and then after $24 \mathrm{~h}$ incubation at $37^{\circ} \mathrm{C}$. The culture was further 10 times diluted and spread on agar and incubated at $37^{\circ} \mathrm{C}$ for $24 \mathrm{~h}$. After this incubation, the $S$. aureus colonies were counted on agar plate by using the colony counter. The colony-forming units of $S$. aureus were counted as a number of colonies multiplied $10^{10} \mu \mathrm{L}^{-1}$.

The antimicrobial testing was performed qualitatively for turbidity analysis by using T60 spectrophotometer (PG Instruments Ltd, UK). Pure 3 to 5 selected colonies of $S$. aureus were cultured in a test tube containing nutrient broth and incubate at $37^{\circ} \mathrm{C}$ for $24 \mathrm{~h}$. After $24 \mathrm{~h}$ incubation, the fresh culture of this bacteria was re-cultured in a nutrient broth 10:1 (10 mL broth and $1 \mathrm{~mL}$ bacterial culture) into three test tubes. Tube one containing $10 \mathrm{~mL}$ nutrient broth along with rosin maleic anhydride and $1 \mathrm{~mL}$ bacterial culture, tube two containing $10 \mathrm{~mL}$ nutrient broth along with pure rosin and $1 \mathrm{~mL}$ bacterial culture and tube three containing only $10 \mathrm{~mL}$ nutrient broth and $1 \mathrm{~mL}$ bacterial culture as a control for turbidity analysis. By using a spectrophotometer, the turbidity of culture was measured at $650 \mathrm{~nm}$ wavelength and taken absorbance from zero time to $24 \mathrm{~h}$ at different intervals of times up to $24 \mathrm{~h}$ for each treatment. By using Origin Pro software, version 9.0.0 (Origin Lab Corporation, Northampton, MA, USA), predicted the response of $S$. aureus under treatment according to Equation 2 adopted from literature ${ }^{[23]}$. 


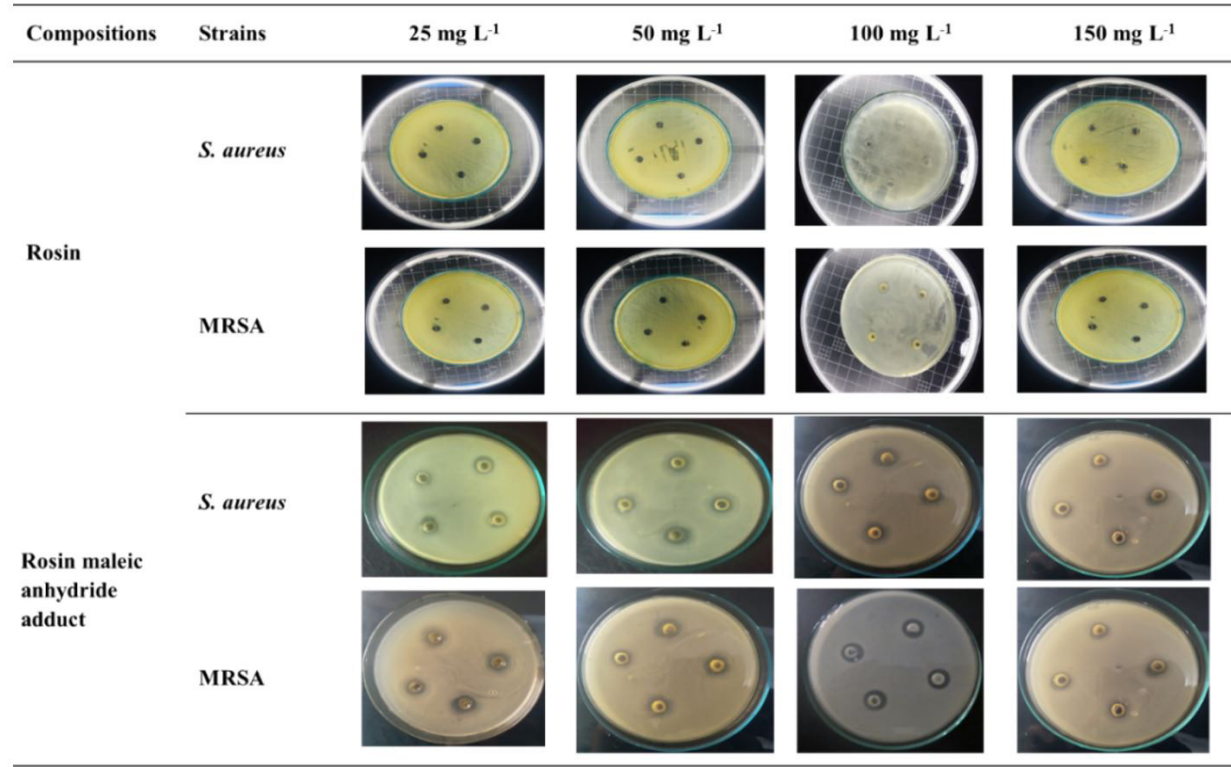

Figure 1. Different concentrations of rosin and rosin maleic anhydride adduct inhibition of MRSA and S. aureus.

$$
X=A \exp \left\{-\exp \left[\frac{\mu_{\mathrm{MAX}} \mathrm{e}}{\mathrm{A}}(\lambda-\mathrm{t})+1\right]\right\}
$$

$X$ is logarithm of the relative population size of $S$. aureus against time; $A$ is asymptote which represents the maximal soil microbial biomass; $t$ is time (h), $\lambda$ is a lag phase (h); $\mu_{M A X}$ is maximum specific growth rate $\left(\right.$ day $\left.^{-1}\right)$ and $e$ is constant.

\section{Results and Discussions}

\subsection{Inhibitory activity of rosin maleic anhydride adduct}

In Figure 1, the inhibitory activity of rosin and rosin maleic anhydride against MRSA and $S$. aureus are shown. At all concentrations, rosin activity was not observed against MRSA and S. aureus. However, the rosin maleic anhydride showed better activity against both MRSA and $S$. aureus. This difference shows successful chemically transformation of rosin into a form that has activity against MRSA and S. aureus. Average data for zone of inhibition recorded for rosin maleic anhydride treated MRSA and S. aureus further revealed in Figure 2, $25 \mathrm{mg} \mathrm{L}^{-1}$ of rosin maleic anhydride effective to inhibit the maximum growth of MRSA. The rosin maleic anhydride at $25 \mathrm{mg} \mathrm{L}^{-1}$ developed $7 \mathrm{~mm}$ of the zone of inhibition. While at the same concentration, a lower value of $4.25 \mathrm{~mm}$ of the zone of inhibition noticed for $S$. aureus treated with rosin maleic anhydride. The further analysis explained that the increase of concentration of rosin maleic anhydride did not increase the zone of inhibition. While an increase of rosin maleic anhydride concentration up to $100 \mathrm{mg} \mathrm{L}^{-1}$ increased the zone of inhibition against $S$. aureus. Therefore, better solubility in water and effectiveness against MRSA made the rosin maleic anhydride a better formulation.

Rosin's activity against MRSA is given in Figure 3. At different concentration rosin, the bacterial culture of MRSA grows up to $24 \mathrm{~h}$. An increase in the concentration

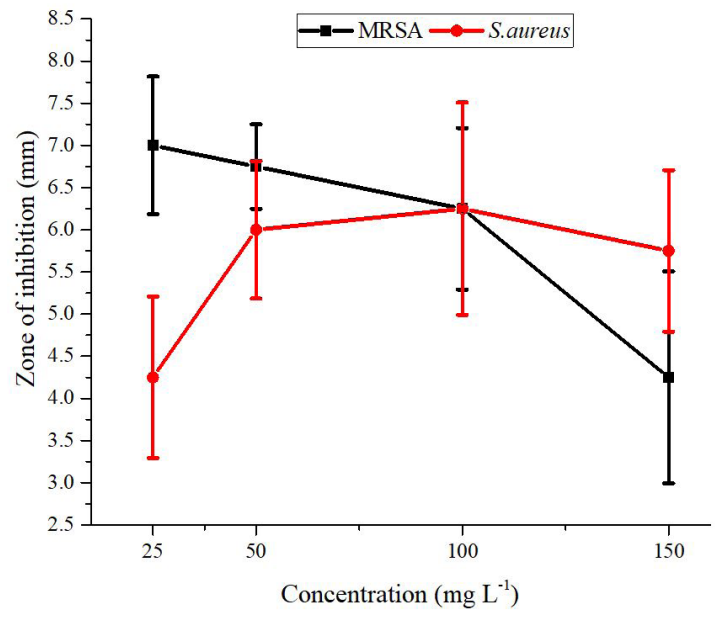

Figure 2. Rosin maleic anhydride inhibitory activity against MRSA and $S$. aureus.

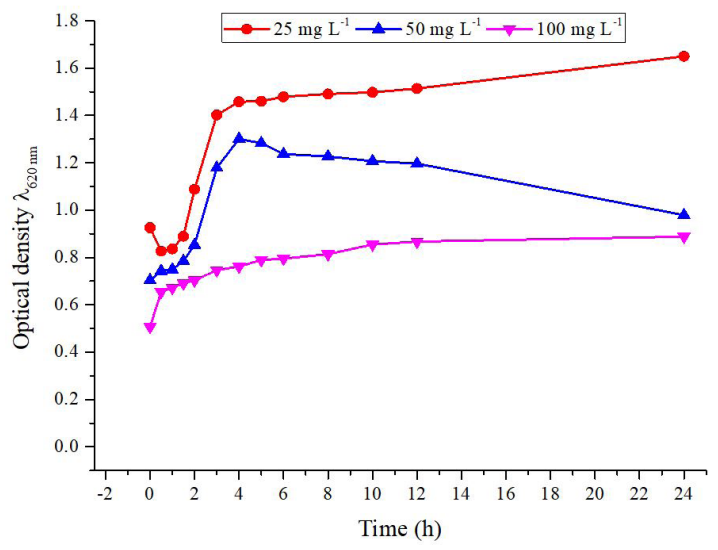

Figure 3. Rosin inhibition of $S$. aureus growth. 
of rosin from 25 to $100 \mathrm{mg} \mathrm{L}^{-1}$ showed significant inhibition of MRSA growth. On day 6 maximum growth for each composition was noticed. Based on optical density at $6 \mathrm{~h}$, the value of optical density was 1.47 for $25 \mathrm{mg} \mathrm{L}^{-1}$ of rosin. The addition of $50 \mathrm{mg} \mathrm{L}^{-1}$ of rosin reduced the optical density of MRSA from 1.47 to 1.23 with a difference of $16.32 \%$ of inhibition. Further increase of rosin up to $100 \mathrm{mg} \mathrm{L}^{-1}$ reduced optical density from 1.47 to 0.79 with a change of $42.25 \%$.

In Figure 4 is given, rosin maleic anhydride activity against MRSA. At different concentration rosin, the bacterial culture of MRSA grows up to $24 \mathrm{~h}$. An increase in the concentration of rosin from 25 to $100 \mathrm{mg} \mathrm{L}^{-1}$ showed significant inhibition of MRSA growth. On day 4 maximum growth for each composition was noticed. Based on optical density at $4 \mathrm{~h}$, the value of optical density was 0.77 for $25 \mathrm{mg} \mathrm{L}^{-1}$ of rosin. The addition of $50 \mathrm{mg}$ of rosin reduced the optical density of MRSA from 0.77 to 0.65 with a difference of $15.58 \%$ of

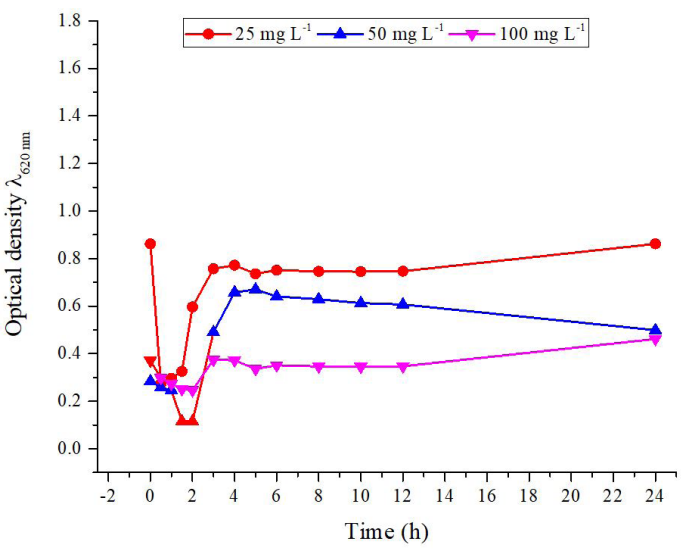

Figure 4. Rosin maleic anhydride adduct inhibition of MRSA growth. inhibition. Further increase of rosin up to $100 \mathrm{mg} \mathrm{L}^{-1}$ reduced optical density from 0.77 to 0.37 with a change of $51.48 \%$. Our findings are in agreement with results ${ }^{[10]}$, rosin has shown inhibitory activity against different fungus and bacterial strains. The possible effect induced by rosin on the strain was due to cell to rosin adhesion.

Figure 5 explains Gompertz kinetics of $S$. aureus and MRSA to find out the growth parameters according to kinetic model Equation 2. The pattern of growth of S. aureus in response to rosin and rosin maleic anhydride fits well to Gompertz parameterization and a reliable prediction through characterization of the curve could be obtained. The parameters obtained after Gompertz kinetic parameters predicted as are given in Table 2 . The asymptote $(A)$ of growth for $S$. aureus showed no significant change in values over an increase in the dosage of rosin. The growth increase was observed at $10.90 \%$ after the rise in the concentration of rosin. In case, the increase of concentration of rosin maleic anhydride causes significant decrease (69.36\%) in $S$. aureus growth parameters. The $\mu_{M A X}$ of $S$. aureus shows a different trend for rosin and rosin maleic anhydride. As noticed $\mu_{M A X}$ declined $85.03 \%$ for an increase in dosages of rosin. This trend deviates when $S$. aureus was treated with rosin

Table 2. Rosin and rosin maleic anhydride adduct effect on growth kinetics of MRSA.

\begin{tabular}{lccccc}
\hline Composition & $\begin{array}{c}\text { Conc. } \\
\left(\mathbf{m g ~ L}^{-1}\right)\end{array}$ & $\boldsymbol{A}$ & $\begin{array}{c}\boldsymbol{\mu}_{\boldsymbol{M A X}} \\
\left(\mathbf{h}^{-1}\right)\end{array}$ & $\begin{array}{c}\boldsymbol{\lambda} \\
(\mathbf{h})\end{array}$ & $\begin{array}{c}\boldsymbol{t}_{\boldsymbol{i}} \\
(\text { day) }\end{array}$ \\
\hline Rosin & 25 & 0.486 & 0.401 & 0.179 & 2.089 \\
& 50 & 0.537 & 0.386 & 0.197 & 1.885 \\
& 100 & 0.539 & 0.060 & 0.204 & 0.000 \\
Rosin maleic & 25 & 1.221 & 0.716 & 0.449 & 1.347 \\
Anhydride & 50 & 0.771 & 2.409 & 0.284 & 2.874 \\
adduct & 100 & 0.374 & 2.403 & 0.138 & 2.360 \\
\hline
\end{tabular}

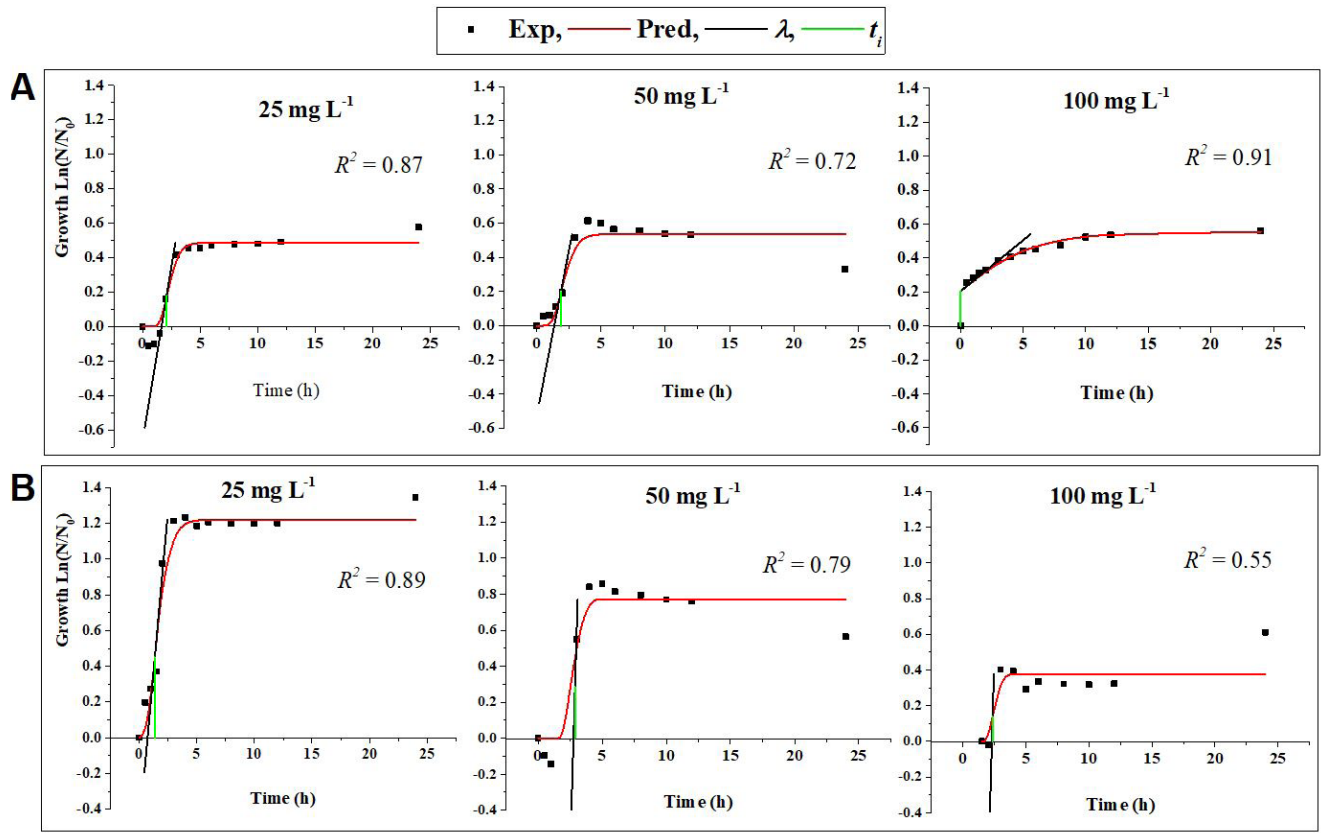

Figure 5. Gompertz kinetic model fitting to growth data of MRSA at different inhibitory concentrations of rosin (A) and rosin maleic anhydride adduct (B) over different incubation hours. 
maleic anhydride. The $\mu_{\max }$ response was $72.20 \%$ higher when $S$. aureus was treated with rosin maleic anhydride. Rosin's treatment prolonged the lag period $(\lambda)$ for the growth of $S$. aureus. The change in the lag period was $13.96 \%$. In contrast, the use of rosin maleic anhydride preferably impacts more on minimizing the lag phase which determines the early growth response of $S$. aureus.

The reduction in lag phase was $69.26 \%$ after an increase of rosin maleic anhydride. The inflection point which determines the shape of the growth curve. This change was higher in the case of rosin maleic anhydride compared to rosin with an opposite trend over the time of growth.

\section{Conclusion}

This work concludes that the adduct form of rosin with maleic anhydride is an effective means of improving the rosin bacteriostatic and inhibitory action against $S$. aureus in general and MRSA in particular. In Pakistani Hospitals, MRSA is prevalent and is found resistant against oxacillin and vancomycin. This work provides a solution to this problem successfully by increasing the efficacy of the rosin after its modification. MRSA could be treated with a dose of $25 \mathrm{mg} \mathrm{L}^{-1}$ rosin maleic anhydride adduct. Rosin maleic anhydride adduct was better metabolized compared to rosin in MRSA supported with a rise in specific growth rate $\left(\mu_{M A X}\right)$ reciprocate with short lag phase $(\lambda)$ data.

\section{Acknowledgements}

Authors are highly grateful to the Department of Biotechnology, University of Azad Jammu \& Kashmir, Muzaffarabad for financial and technical support and the Deanship of Scientific Research at Najran University, Najran, Saudi Arabia for a financial assistant to publish this research work successfully.

\section{References}

1. Seyfried, P. L., Tobin, R. S., Brown, N. E., \& Ness, P. F. (1985). A prospective study of swimming-related illness. II. Morbidity and the microbiological quality of water. American Journal of Public Health, 75(9), 1071-1075. http://dx.doi.org/10.2105/ AJPH.75.9.1071. PMid:4025657.

2. McDougal, L. K., Steward, C. D., Killgore, G. E., Chaitram, J. M., McAllister, S. K., \& Tenover, F. C. (2003). Pulsed-field gel electrophoresis typing of oxacillin-resistant Staphylococcus aureus isolates from the United States: establishing a national database. Journal of Clinical Microbiology, 41(11), 51135120. http://dx.doi.org/10.1128/JCM.41.11.5113-5120.2003. PMid:14605147.

3. Witte, W., Strommenger, B., Klare, I., \& Werner, G. (2004). Antibiotic-resistant nosocomial pathogens. Part I: diagnostic and typing methods. Bundesgesundheitsblatt, Gesundheitsforschung, Gesundheitsschutz, 47(4), 352-362. http://dx.doi.org/10.1007/ s00103-004-0810-y. PMid:15205778.

4. Yau, V., Wade, T. J., de Wilde, C. K., \& Colford, J. M., Jr. (2009). Skin-related symptoms following exposure to recreational water: a systematic review and meta-analysis. Water Quality, Exposure, and Health, 1(2), 79-103. http://dx.doi.org/10.1007/ s12403-009-0012-9.

5. McCarthy, A. J., Witney, A. A., \& Lindsay, J. A. (2012). Staphylococcus aureus temperate bacteriophage: carriage and horizontal gene transfer is lineage associated. Frontiers in Cellular and Infection Microbiology, 2, 6. http://dx.doi. org/10.3389/fcimb.2012.00006. PMid:22919598.

6. Hartman, B. J., \& Tomasz, A. (1984). Low-affinity penicillinbinding protein associated with beta-lactam resistance in Staphylococcus aureus. Journal of Bacteriology, 158(2), 513-516. http://dx.doi.org/10.1128/JB.158.2.513-516.1984. PMid:6563036.

7. Tavares, A. L. (2014). Community-associated methicillinresistant Staphylococcus aureus (CA-MRSA) in Portugal (Doctoral dissertation). Universidade NOVA de Lisboa, Portugal. Retrieved in 2020, April 18, from https://run.unl. $\mathrm{pt} /$ handle/10362/14236

8. Söderberg, T. A., Gref, R., Holm, S., Elmros, T., \& Hallmans, G. (1990). Antibacterial activity of rosin and resin acids in vitro. Scandinavian Journal of Plastic and Reconstructive Surgery and Hand Surgery, 24(3), 199-205. http://dx.doi. org/10.3109/02844319009041279. PMid:2281306.

9. Sipponen, A., \& Laitinen, K. (2011). Antimicrobial properties of natural coniferous rosin in the European Pharmacopoeia challenge test. APMIS, 119(10), 720-724. http://dx.doi. org/10.1111/j.1600-0463.2011.02791.x. PMid:21917009.

10. Jindal, R., Sharma, R., Maiti, M., Kaur, A., Sharma, P., Mishra, V., \& Jana, A. (2017). Synthesis and characterization of novel reduced gum rosin-acrylamide copolymer-based nanogel and their investigation for antibacterial activity. Polymer Bulletin, 74(8), 2995-3014. http://dx.doi.org/10.1007/s00289-016-1877-y.

11. Santovito, E., Neves, J., Greco, D., D’Ascanio, V., Sarmento, B., Logrieco, A. F., \& Avantaggiato, G. (2018). Antimicrobial properties of rosin acids-loaded nanoparticles against antibioticsensitive and antibiotic-resistant foodborne pathogens. Artificial Cells, Nanomedicine, and Biotechnology, 46(Suppl 3), S414-S422. https://doi.org/10.1080/21691401.2018.1496 924.

12. Sipponen, A., Peltola, R., Jokinen, J. J., Laitinen, K., Lohi, J., Rautio, M., Männistö, M., Sipponen, P., \& Lounatmaa, K. (2009). Effects of Norway spruce (Picea abies) resin on cell wall and cell membrane of Staphylococcus aureus. Ultrastructural Pathology, 33(3), 128-135. http://dx.doi. org/10.1080/01913120902889138. PMid:19479653.

13. Atta, A. M., \& Elsaeed, A. M. (2011). Use of rosin-based nonionic surfactants as petroleum crude oil sludge dispersants. Journal of Applied Polymer Science, 122(1), 183-192. http:// dx.doi.org/10.1002/app.34052.

14.

Karlberg, A. T., \& Hagvall, L. (2018). Colophony: Rosin in unmodified and modified form. In T. Rustemeyer, P. Elsner, S. M. John \& H. I. Maibach (Eds.), Kanerva's occupational dermatology (pp. 607-624). Berlin Heidelberg: Springer. http://dx.doi.org/10.1007/978-3-31940221-5_41-2.

15. Mumtaz, I., Majeed, Z., Ajab, Z., Ahmad, B., Khurshid, K., \& Mubashir, M. (2019). Optimized tuning of rosin adduct with maleic anhydride for smart applications in controlled and targeted delivery of urea for higher plant's uptake and growth efficiency. Industrial Crops and Products, 133, 395-408. http:// dx.doi.org/10.1016/j.indcrop.2019.02.036.

16. National Center for Biotechnology Information PubChem Database. Retrieved in 2020, April 18, from https://pubchem. ncbi.nlm.nih.gov/compound/Rosin

17. Johnson, T. R., Case, C. L., Cappuccino, J. G., \& Sherman, N. (2013). Great adventures in the microbiology laboratory: microbiology 22. UK: Pearson Learning Solutions.

18. Ekawati, E. R., Darmanto, W., \& Wahyuningsih, S. P. A. (2020). Detection of Staphylococcus aureus in wound infection on the skin surface. IOP Conference Series: Earth and Environmental 
Science, 456, 012038. http://dx.doi.org/10.1088/17551315/456/1/012038.

19. Nathwani, D. (2018). Overview of AMR. In British Society for Antimicrobial Chemotherap(Ed.), Antimicrobial stewardship: from principles to practice (Chap. 1, pp. 12-26). UK: British Society for Antimicrobial Chemotherap. Retrieved in 2020, April 18, from http://www.bsac.org.uk/antimicrobialstewardshipebook/BSACAntimicrobialStewardship-FromPrinciplestoPractice-eBook.pdf

20. Almutairi, M. S., Zakaria, A. S., Ignasius, P. P., Al-Wabli, R. I., Joe, I. H., \& Attia, M. I. (2018). Synthesis, spectroscopic investigations, DFT studies, molecular docking and antimicrobial potential of certain new indole-isatin molecular hybrids: experimental and theoretical approaches. Journal of Molecular Structure, 1153, 333-345. http://dx.doi.org/10.1016/j. molstruc.2017.10.025.

21. Hussain, S. S., HusseinAlwan, A., Abbas, M., \& Tektook, N. K. (2019). Biochemical and molecular diagnosis of Escherichia coliand Pseudomonas aeruginosa isolated from UTI patients. In The First International Scientific Conference of Health and
Medical Specialties (pp. 12-30). Iraq: Kut Technical Institute, Middle Technical Universty. Retrieved in 2020, April 18, from http://kti.mtu.edu.iq/conf/researches/3.pdf

22. Corey, B. W., Thompson, M. G., Hittle, L. E., Jacobs, A. C., Asafo-Adjei, E. A., Huggins, W. M., Melander, R. J., Melander, C., Ernst, R. K., \& Zurawski, D. V. (2017). 1, 2, 4-triazolidine3-thiones have specific activity against Acinetobacter baumannii among common nosocomial pathogens. ACS Infectious Diseases, 3(1), 62-71. http://dx.doi.org/10.1021/acsinfecdis.6b00133. PMid:27764938.

23. Majeed, Z., Mansor, N., ismail, S., Mathialagan, R., \& Man, Z. (2016). Gompertz kinetics of soil microbial biomass in response to lignin reinforcing of urea-crosslinked starch films. Procedia Engineering, 148, 553-560. http://dx.doi.org/10.1016/j. proeng.2016.06.510.

Received: Apr. 17, 2020

Revised: July 19, 2020

Accepted: July 24, 2020 